\title{
Sustainability of rural electrification programs based on off-grid photovoltaic (PV) systems in Chile
}

\author{
Sarah Feron ${ }^{1 *}$, Harald Heinrichs ${ }^{1}$ and Raul R. Cordero $^{2}$
}

\begin{abstract}
Background: Mainly based on expanding the grid, Chile has reached an impressive electrification rate. However, due to unviable grid expansion to islands and remote areas of the country, the government started implementing off-grid electrification programs. In this paper, we assess the sustainability of rural electrification efforts in Chile paying special attention to off-grid photovoltaic (PV) programs.

Methods: Our assessment of the rural electrification efforts in Chile takes into account four dimensions of sustainability (institutional, economic, environmental, and socio-cultural). It is based on an extensive qualitative document analysis, complemented by semi-structured interviews to key stakeholders.

Results: We found that, despite several successful pilot off-grid PV projects, the deployment of off-grid PV solutions for rural electrification lagged behind the enormous solar potential of the country. Part of the problem is that decisions favoring other technologies have been made without considering costs over the lifetime and environmental co-impacts. Moreover, the social acceptance of off-grid PV solutions has been seriously compromised due to problems regarding the accuracy (systems were unable to meet the user's needs) and reliability (systems often failed due to lack of mandatory standards and the uncertain maintenance).

Conclusions: Although Chile has conducted remarkable efforts on electrification during the last 20 years, the indigenous communities still have less access to electricity. This disparity is a major drawback that underscores the need for adjusting the electrification approach (which means that the communities or the local authorities have to request electrification at first place) adopted by the Ministry of Energy in rural electrification. Indeed, this approach favors better organized communities leaving behind others-normally the poorest indigenous communities. Moreover, major progress on cultural justice, equity, and environmental awareness is needed for ensuring the sustainability of rural electrification efforts in Chile.
\end{abstract}

Keywords: Off-grid PV, Rural electrification, Sustainable energy

\section{Background}

\section{Introduction}

The United Nations established the Sustainable Energy for All (SE4All) initiative in 2011 [1]. According to this initiative, sustainable energy not only seeks access to modern and clean energy but it must also embrace energy efficiency and the use of renewable energies (RE) [1]. Indeed, developing countries (DC) still have the

\footnotetext{
* Correspondence: Sarah.Feron@stud.leuphana.de

'Leuphana University Lüneburg, Scharnhorststraße 1, 21335 Lüneburg, Germany

Full list of author information is available at the end of the article
}

chance to provide cleaner and more efficient energy to their citizens that do not have access yet, thus omitting the process of technological development undergone by the developed countries [1]. This is an important opportunity, since by 2013, 1.2 billion people worldwide were still lacking access to electricity [2]. Great differences remain concerning the access to electrification between the urban and the rural sector. From a global perspective, while $94 \%$ of the urban population is electrified, its number is much lower in the rural case, with a rate of only $68 \%$ [2]. 
Chile has reached an impressive rural electrification rate of $97.3 \%$ (whereas in 1992, it was only 53\%) [3, 4]. This achievement has been mainly based on expanding the grid. Yet, despite this attainment, there are still about 20,000 people-almost exclusively in rural areas-that do not have access to electricity [5]. Due to unviable grid expansion to islands and remote areas of the country, the government started looking for alternatives. In 2001, the "Removal of barriers for rural electrification with Non-Conventional Renewable Energies" program was launched to further improve the rural electrification rate by deploying Non-Conventional Renewable Energies (NCRE).

While prior efforts have pointed out that northern Chile is the place where the highest surface irradiance is likely to occur $[6,7]$, most of the Chilean territory has a significant solar potential [8]. However, the deployment of solar technologies in Chile has historically lagged behind that potential. Only in recent years, the solar energy in Chile has experienced high growth rates: e.g., while in 2012 the installed photovoltaic (PV) capacity was insignificant, in December 2015, the power capacity of grid-connected utility-scale PV plants peaked at 0.75 GWp [9]. However, despite some successful pilot programs, little attention has been paid to off-grid PV systems in Chile as a tool for rural electrification.

In this paper, we assess the sustainability of rural electrification efforts in Chile, addressing the following research question: Are the Chilean rural electrification efforts based on off-grid PV systems sustainable?

In order to answer our research question, we conducted an exhaustive qualitative document analysis for social sciences ([10], p. 29), complemented by semistructured interviews with key stakeholders. According to the approach broadly used for the assessment of sustainability (see, for example, [11-15]), the interviewed stakeholders included representatives from different Ministries (Energy, Social Development, Agriculture), non-profit organizations (NPOs), private companies, and universities. Although below we describe several relevant PV-based electrification efforts in Chile, our research was aimed at gathering an overall picture of the rural electrification efforts in the country, rather than measuring the success or failure of a specific project.
The gathered information allowed us to assess the sustainability of rural electrification efforts in Chile. Our assessment was based on a set of indicators (see Table 1) corresponding to the four dimensions of sustainability considered in this paper: institutional, economical, environmental, and socio-cultural; see, e.g., [16-18].

\section{Theoretical framework}

Institutional sustainability demands for stability/durability (e.g., [19-23]) and technical and service standards, as well as coherence between laws and regulations ([17, 19, 22-24]). Failures in rural electrification have often been attributed to the lack of coherence in the legal frame (laws, regulations, and standards) $[19,22,23]$ or the absence of proper standards (e.g., $[25,26])$. White et al. [27] have also shown how unexpected policy changes can have negative impacts on investments and cause uncertainty. Furthermore, numerous studies have underscored the fact that sustainable institutions should have the ability to adapt to future needs of the population (e.g., $[19,22,28-31])$.

Sustainable institutions not only need to preserve themselves over time but they should also be open to the society and its interests and be accountable and transparent in their decision-makings, while equally considering the other sustainability dimensions [17]. Therefore, decentralization and participation has often been mentioned as an indicator for sustainable institutions (e.g., [16, 19, 24, 31-34]). Wüstenhagen et al. [35] argue that a top-down approach at the central government level may inhibit the acceptance of a technology at the local level. Despite the advantages of decentralization, Rondinelli et al. [36] have pointed out the fact that decentralization may be problematic if local institutions in a decentralized administration lack the expertise, know-how, and management capacity to administrate the services.

Economic sustainability of electrification solutions requires ensuring the funding or affordability of the systems (i.e., the initial investments and the operation and maintenance (O\&M) over its lifetime) (e.g., [20, 22, $30,33,37-40])$. In the energy sector, other import indicators for economic sustainability of electrification solutions are the cost-effectiveness (e.g., $[19,22,39])$ and the

Table 1 Indicators for sustainability of off-grid PV systems in Chile (adapted from [15])

\begin{tabular}{|c|c|c|c|}
\hline Institutional & Economic & Environmental & Social/cultural \\
\hline Stability (durability) and long-term vision & Cost-effectiveness & $\begin{array}{l}\text { Environmental } \\
\text { awareness }\end{array}$ & $\begin{array}{l}\text { Accessibility (disparity, } \\
\text { equity) }\end{array}$ \\
\hline Regulation, standards, and enforcement & Reliability & Environmental impact & Social acceptance \\
\hline $\begin{array}{l}\text { Decentralization and openness to } \\
\text { participation }\end{array}$ & $\begin{array}{l}\text { Funding (initial investment, operation, and } \\
\text { maintenance) }\end{array}$ & & Accuracy \\
\hline Adaptability (ability to meet future needs) & Contribution to income of users & & Cultural justice \\
\hline
\end{tabular}


reliability of supply (see, e.g., [19, 22, 23, 28, 41, 42]). Moreover, since energy consumption is correlated with income, efforts on rural electrification are expected to contribute to the income of its users (e.g., [19, 39, 43-45]). However, if energy projects aim at a higher productive outcome of rural communities, electrification programs need to be coupled with complementary infrastructure, including training and education [45].

Ensuring the environmental sustainability for rural electrification requires civil society's awareness on environmental issues, as their support is needed to enforce environmental policies and regulations [46]. Environmental sustainability also requires minimizing negative impacts of energy solutions on the environment. These impacts may concern the amount of greenhouse gases (GHG) such as $\mathrm{CO}_{2}, \mathrm{SO}_{2}$, or $\mathrm{NO}$ (see, e.g., [22, 30, 31, $39,41,42,44,47,48]$ ); a loss of biodiversity due to deforestation [22, 39, 42, 48]; or local impacts such as air quality caused by pollution in households, noise, or aesthetical disturbances [22, 42, 44, 48-50].

Socio-cultural sustainability requires considering equity/ disparity criteria between different communities. In rural electrification, decisions have to be made regarding who will have access to energy (first) and how much energy is provided to each household [30, 32, 39, 48, 51]. Furthermore, attention must be paid to the accuracy of a technology for the specific environmental/socio-cultural conditions where it will be implemented [22, 52], as well as to the social acceptance, which implies a participatory and inclusive approach in which the local community is engaged to increase accountability $[35,42,53]$. It is therefore vital for ensuring socio-cultural sustainability, embracing the notion of cultural justice, which in this context refers to justice through participation and recognition [54]. The cultural justice in rural electrification depends on the ability shown to integrate the technology into the existing social structures [22, 30, 42, 47]. Indeed, as argued elsewhere (e.g., [28, 55]), the socio-cultural context determines to what extent a technology is adopted.

Based on this theoretical framework, we built up a set of indicators (see Table 1). These indicators were qualitatively evaluated and allowed us to assess the sustainability of the rural electrification efforts in Chile based on off-grid PV systems.

\section{Chile}

\section{General background on Chile}

Chile is a South American country of about $756,950 \mathrm{~km}^{2}$ with a coastline of $6435 \mathrm{~km}$ and borders with Argentina, Peru, and Bolivia. The geography of Chile is extremely diverse as the country extends from latitude $17^{\circ}$ South to $56^{\circ}$ South and from the Pacific Ocean on the west to the Andes on the east. Considerable climate differences can be found from the extremely arid desert in the
North (the Atacama Desert), through the semiarid central Chile with Mediterranean climate, to the cooler and rainy southern Chile. The extreme geography of the country is one of the reasons for the isolation of communities in northern and southern Chile [56].

Chile's population was about 17.6 million in 2013, of which $10.6 \%$ was rural. The latter has been declining during the last 10 years by an annual average of approximately 1.3\% [57]. In 2014, Chile's gross domestic product per capita amounted to US\$ 21,800 [57]. The Chilean economy is highly dependent on the mining industry, which represents $54.2 \%$ of its exports [58]. Due to its stable economic framework, foreign direct investments (FDI) have increased considerably, reaching a record of US\$ 11.9 billion in 2014, of which electricity, gas, and water have a stake of $17.7 \%$ [58]. The country could halve its poverty rate from $29.1 \%$ (extreme poverty of $12.6 \%$ ) in 2006 to $14.4 \%$ (extreme poverty of $4.5 \%$ ) in 2013 [59]. Nevertheless, inequality is still a major issue: with a GINI Index (see [60] for details) of 50.5, Chile is the country with the most unequal income distribution in the Organisation for Economic Co-operation and Development (OECD) [57, 61]. This is especially true for minorities [56], e.g., extreme poverty is higher for indigenous populations (4.3\%) than for non-indigenous populations $(2.7 \%)$ [62].

Chile is a democratic presidential republic that accounts for 15 "regions" or territories, 54 provinces, and 346 boroughs (municipalities). The regional governments (GOREs by its Spanish acronym) are constituted by a regional ministerial representative (appointed by the President of the Republic) and a regional council (CORE by its Spanish acronym) whose members are elected by the citizens. The main function of the GORE is to advocate for the territorial development. The GORE initiatives are funded by the National Development Fund (FNDR by its Spanish acronym) [63] that depends on annual national budget. The GORE of each region can distribute its funds according to the needs in different sectors including electrification, education, health, drinking water, and routes [5].

Each province is headed by a governor (also appointed by the President of the Republic), whose main role consists of assuring internal security [64]. The boroughs or groups of several boroughs rely on municipalities governed by a mayor elected by the citizens, whose functions include planning and regulations and development of infrastructure and services, as well as environmental protection [63].

Regarding this research, there are two additional relevant institutions in the country. First is the Subsecretary of Regional Development and Administration (SUBDERE by its Spanish acronym) that is in charge of the coordination and promotion of the regional development by 
means of the regional and municipal governance; it strengthens technical and institutional capacities of these administrations and administrates funds [65]. Second is the Regional Secretaries of the Ministries (SEREMIs by its Spanish acronym) that though operating in the regions are controlled by the Ministries of the central government [63].

Despite prior attempts of decentralization (e.g., in 2000, 2004, 2008, and 2011), the central government remains highly concentrated $[66,67]$. This is mainly due to two factors: the lack of financial autonomy (regional/ local governments financially depend on the central administration) and the lack of administrative autonomy (due to a rigid organization) [63].

\section{Electrification in Chile}

Chile's electricity sector was publically held until the National Energy Commission (CNE by its Spanish acronym; founded in 1978) enacted the Electricity Act in 1982, which drove privatization and allowed for competition in generation and distribution $[68,69]$. The Electricity Act was reformed in 2004 and 2005 by Laws 19.940 and 20.018 ("Ley Corta" I and II) that aimed to foster further competition. The electricity distribution companies (EDCs) operating in Chile (currently 33) are hence privately held. The EDCs are obliged by law to provide the service in the area where they own a concession even if it results in a loss for them.

In 2010, a new law (No. 20.402) created the Ministry of Energy, which took over part of the tasks from the $\mathrm{CNE}$ and is in charge of the energy policy and planning. The role of the CNE changed thereinafter, making it responsible for setting prices, tariffs, and technical norms [70]. Moreover, the Electricity and Fuel Authority (SEC by its Spanish acronym) is responsible in Chile for monitoring the compliance with laws, regulations, and technical standards for a proper operation of the energy sector (including pricing, energy quality, and security) [71]. The Centre for Renewable Energy (CER by its Spanish acronym) is another important institution of the energy sector; it was renamed in 2014 to the Centre for Innovation and Promotion of Sustainable Energy (CIFES by its Spanish acronym). The CIFES aims to promote the design, implementation, and evaluation of strategic sustainable energy projects [9].

Regarding electricity generation, about $30 \%$ of the installed capacity in 2015 was hydropower, 18\% diesel, $20.5 \%$ carbon, and 13\% NCRE, including $4.26 \%$ stemming from solar energy [72]. In 2008, Chile adopted a renewable energy target that, although subsequently modified, nowadays states that by 2025 electricity companies that inject energy into the two major electricity systems, the Northern Interconnected System (SING by its Spanish acronym) and the Central Interconnected
System (SIC by its Spanish acronym) [73], must ensure that $20 \%$ of the annual energy consumption is met by non-conventional renewable generators [74-75].

In recent years, RE in Chile has experienced high growth rates: e.g., while in 2012 only 2 MWp of PV had been installed, in December 2015, the installed power capacity of NCRE had increased to $2.6 \mathrm{GWp}$ (thereof solar PV $0.75 \mathrm{GWp}$ ), and another $2.7 \mathrm{GWp}$ is currently under construction [9]. This boom has been driven by the high energy prices in Chile combined with ideal conditions for the generation of solar energy, which motivated mainly foreign companies to invest in utility-scale power plants, especially in northern Chile. In the case of the small-scale NCRE plants (up to $100 \mathrm{kWp}$ ), further progress is expected due to the new Law No. 20.571 "Net Metering" that allows feeding-in electric energy surpluses into the grid for a reward [76].

\section{Rural electrification in Chile}

In 1992, the urban Chilean electrification rate reached $97 \%$, although in rural areas only $53 \%$ of the population had access to electricity [69]. Attending this deficit, in 1994, the CNE launched the National Program for Rural Electrification (PER by its Spanish acronym), which was funded by the FNDR. The PER allowed gradually increasing the rural electrification rate to $75 \%$ in 1999 and $97.3 \%$ in 2013 [3, 4]. Yet, this remarkable achievement was mainly based on grid expansions. In 2001, the central government looked for an alternative for electrification in the case of highly dispersed inhabitants of remote areas. That year, the "Removal of barriers for rural electrification with NCRE" program was launched to further improve the rural electrification rate.

In 2009, the CNE created a program called the National Program on Rural and Social Energy (PERYS by its Spanish acronym). The PERYS program focuses on (1) the electrification of rural schools and small health centers, (2) the incorporation of solar thermal systems in public buildings, and (3) the implementation of NCRE systems for small-scale productive uses. The PERYS program depends on the Ministry of Energy and its Department of Energy Access and Equity (DAEE by its Spanish acronym). This Department is embedded with the SEREMIs, and it took over the rural electrification area from the CNE. The DAEE also developed the rural electrification strategy for the upcoming years (2015-2018), which is supposed to favor NCRE solutions [5].

Rather than a top-down approach, the DAEE favors a bottom-up approach, which means that the communities have to request electrification at first place. The request is normally directed to the mayor of the municipality on which the community depends. Whether or not a municipality conducts a project on its own account depends on the project size (i.e., the budget): Projects with 
a budget of up to 70 million Chilean pesos (approx. US\$ $120,000)$ can be directly executed by the municipality without further formal requirements. However, projects that exceed this amount need a formal request to the GORE to apply for funds from the FNDR. This formal process comprises a feasibility study of the project to select the appropriate technological and administrative design for the particular circumstances in a community; it concerns the price and capacity of the energy supply, the quality of the service, and the O\&M model. Additionally, the study requires approval from the DAEE (at the respective SEREMI).

The projects selected by the GORE are carried out by a private company selected by a call for bid. Whether or not the tender covers only the initial installation or also the O\&M of the systems depends on the project's selected O\&M model. The latter is project-specific, and the systems can be operated either by the community via a cooperative or by a private company against a compensation fee [77].

In the case of off-grid systems, there are no regulations on the power capacity of the projects (i.e., neither a minimum nor a maximal power capacity per household). The O\&M costs of the off-grid PV systems are not regulated either, and therefore, they are determined based on project-specific agreements between the municipality and the partner in charge of the O\&M (either a private company or a cooperative). However, the funds are expected to cover all the O\&M costs $[78,79]$.

The projects selected by the GORE (funded by the FNDR) are centrally registered in an Integrated Project Database (BIP by its Spanish acronym), which is administrated by the Ministry of Development. The BIP not only assures traceability of all projects (thus avoiding duplications) but it also allows the GORE to prioritize and select the projects that will receive funds from the FNDR.

Although the tariff for off-grid is not regulated, in the case of off-grid PV projects, the tariff from the closest community connected to the grid is normally adopted. Hence, the monthly tariff is set per unit price of energy from the neighboring community and multiplied by the energy that will approximately be generated by the installed PV system [80]. Since this tariff can hardly cover the O\&M costs, subsidies can be requested to the GORE (although they must be evaluated and approved each year by the respective SUBDERE).

Table 2 provides an overview of the rural electrification programs in Chile (including those aimed at productive uses) that have been considered in this paper. In addition to the PER and the PERYS programs, we also considered a micro-grid project (implemented in Huatacondo by a Chilean University and a NPO) and two successful off-grid PV initiatives, the so-called Coquimbo Project and a program of PV-powered water pumps. Due to their importance, the two latter projects are described in detail below.

The "Coquimbo Project" (northern Chile) From 2001 to 2012, the CNE (and later the DAEE) led the program "Removal of barriers for rural electrification with NCRE". The program was partially funded by the Global Environmental Facility (GEF) and supported by the United Nations Development Programme (UNDP). The program aimed to remove institutional, financial, regulative, technological, and knowledge barriers that inhibited the adoption of NCRE in rural areas of the country. The total project costs amounted to about US\$ 32 million, of which the Chilean government contributed around US\$ 26 million and the GEF contributed the remaining US\$ 6 million [81].

Seven of the nine action lines of this program were related to PV. Action line 1 included the comprehensive information gathering across the country, which entailed land registries and a survey of 12,400 households in rural areas concerning their needs and current energy sources used, as well as the available infrastructure. Based on this information, 33 NCRE projects (mainly PV) were implemented [81, 82].

As a part of the program, the CNE/UNDP team also elaborated 15 technical regulations for PV (44 in total) based on international norms (IEC/ISO) and a certification process for PV systems (action lines 2 and 3). The Chilean norms (e.g., NCh2903 for PV systems and NCh2978 for batteries; see [83]) were developed by personnel from the CNE, the National Institute of Normalization (INN by its Spanish acronym), universities, private consultants, and others and thereinafter adopted by the INN. Though these norms are voluntary, supervision as well as the certification is the responsibility of the SEC [81].

The promotional campaign (action line 4) of the program aimed to increase the demand for NCRE. The budget for this line amounted to about US\$ 500,000, which was financed by the GEF and the Chilean Government. A training program was also developed (action line 5) with a budget of US $\$ 536,875$ (mainly funded by the GEF). The program was aimed at central and regional politicians, regulatory agencies, engineers, technicians, and users. Up to 2009, workshops and seminars had been given to about 3500 people, and further efforts for improving capacities were made in government bodies, education centers, and universities, aiming to foster the access to knowledge on NCRE in these organizations [81].

Action line 6 implied the installation of 3064 PV systems for rural households in 15 municipalities in the 
Table 2 Rural electrification projects considered in this paper

\begin{tabular}{|c|c|c|c|c|c|}
\hline & $\begin{array}{l}\text { National Program for Rural Electrification } \\
\text { (PER) (PV projects only) }\end{array}$ & $\begin{array}{l}\text { National Program } \\
\text { on Rural and Social } \\
\text { Energy (PERYS) } \\
\text { (PV projects only) }\end{array}$ & $\begin{array}{l}\text { Huatacondo } \\
\text { micro-grid project }\end{array}$ & $\begin{array}{l}\text { Coquimbo Project } \\
\text { (PV only) }\end{array}$ & $\begin{array}{l}\text { PV-powered } \\
\text { water pumps } \\
\text { program }\end{array}$ \\
\hline $\begin{array}{l}\text { Reports for ex-post } \\
\text { evaluations }\end{array}$ & $\begin{array}{l}\text { Covarrubias et al. [90]; Navarro et al. } \\
\text { [95]; Deuman, [89]; DIPRES [80]; } \\
\text { Comunidades Energéticas [112]; } \\
\text { Ministerio de Desarrollo Social [111]; } \\
\text { Gobierno Regional de Aysén [92] }\end{array}$ & $\begin{array}{l}\text { IEA [113]; Ministerio } \\
\text { de Energía [114] }\end{array}$ & $\begin{array}{l}\text { Jiménez-Estévez } \\
\text { et al. [96]; Núñez } \\
\text { et al. [109] }\end{array}$ & $\begin{array}{l}\text { Rodriguez [82]; } \\
\text { Estay [81] }\end{array}$ & $\begin{array}{l}\text { GreenLab } \\
{[115]}\end{array}$ \\
\hline Program sponsored by & CNE/Ministry of Energy (GOREs) & Ministry of Energy & $\begin{array}{l}\text { University of } \\
\text { Chile/NPO }\end{array}$ & $\begin{array}{l}\text { CNE/Ministry of } \\
\text { Energy, GEF, UN }\end{array}$ & $\begin{array}{l}\text { Agency for } \\
\text { Agrarian } \\
\text { Development } \\
\text { (INDAP) }\end{array}$ \\
\hline Location & $\begin{array}{l}\text { Curepto/Pencahue (Maule region); } \\
\text { Cochrane (Aysén region; regions of } \\
\text { Tarapacá, Coquimbo, and Maule) }\end{array}$ & Nationwide & $\begin{array}{l}\text { Huatacondo } \\
\text { (region of } \\
\text { Tarapacá; } \\
\text { northern Chile) }\end{array}$ & Coquimbo & Nationwide \\
\hline Energy use & $\begin{array}{l}\text { Residential rural electrification; } \\
\text { electrification of schools/health } \\
\text { centers/social buildings }\end{array}$ & $\begin{array}{l}\text { Electrification of } \\
\text { schools/health } \\
\text { centers/social } \\
\text { buildings/public } \\
\text { lightning }\end{array}$ & $\begin{array}{l}\text { Residential rural } \\
\text { electrification and } \\
\text { productive use }\end{array}$ & $\begin{array}{l}\text { Residential rural } \\
\text { electrification }\end{array}$ & $\begin{array}{l}\text { Productive } \\
\text { use }\end{array}$ \\
\hline Capacity/sizing & Between 50 and $600 \mathrm{Wp}$ per dwelling & $\begin{array}{l}\text { Between } 380 \mathrm{Wp} \\
\text { and } 4 \mathrm{kWh} \text { per } \\
\text { project }\end{array}$ & $\begin{array}{l}\text { 22.68-kW PV } \\
\text { plant + 120-kVA } \\
\text { diesel group for } \\
\text { a community }\end{array}$ & 125 Wp per dwelling & $\begin{array}{l}\text { Three different } \\
\text { kits available: } \\
\text { 230/690/1380 } \\
\text { Wp per farmer }\end{array}$ \\
\hline Year of installations & Since 1997 & Since 2009 & 2009 & $2001-2012$ & $2012-2013$ \\
\hline $\begin{array}{l}\text { Number of installations/ } \\
\text { households electrified }\end{array}$ & $\begin{array}{l}\text { Solar home systems (SHS) 12,565; } \\
\text { schools } 87 ; \text { health centers 14; } \\
\text { productive use: } 6\end{array}$ & 83 & $\begin{array}{l}\text { About } 100 \\
\text { people }\end{array}$ & $\begin{array}{l}3064 \text { SHS (new); } 1500 \\
\text { (improvements); } \\
55 \text { schools and } \\
\text { health centers }\end{array}$ & 1876 \\
\hline
\end{tabular}

Sources: own elaboration based on information from $[82,111,89,116,85]$

Coquimbo region. The systems were funded by the FNDR (US\$ 5 million). The National Electrical Force Company (CONAFE by its Spanish acronym), a private EDC that operates in the regions of Coquimbo and Valparaíso (serving almost 500,000 clients), installed the PV systems from 2005 to 2006 and has furthermore been in charge of the O\&M of the systems for a period of 10 years (with an option for renewal) [81]. The action line 7 aimed to promote productive uses (e.g., for farming) based on NCRE. This action line was funded (US\$ 25 million) by the Chilean government and until 2010 led to several demonstration-scale PV-powered water pump projects for irrigation [81].

The success of the program ultimately sought to pave the way for the implementation of further projects based on NCRE in remote areas across the country.

PV-powered water pumps The CNE/UNEP program also favored projects for productive uses implementing five demonstration systems for PV-powered water pumps. These pilots helped to raise the interest of the PV technology in the Ministry of Agriculture. Indeed, some of the (10) subdivisions and agencies of the Ministry of Agriculture have successfully adopted and transferred these systems to farmers after the end of the CNE/UNEP program in 2010.

The Chilean Agency for Agrarian Development (INDAP by its Spanish acronym) was the agency that promoted to replace with PV-powered water pumps existing systems powered by diesel generators. The systems consist of a PV panel, a pump, and a controller, and they were designed with no critical parts like batteries or inverters (pumps are directly connected to the PV modules). These decisions were meant to ensure high durability and low maintenance. The Agency participated in the design of the systems and set particular value on quality standards. Currently, three different kits $(230,690$, and $1380 \mathrm{Wp})$ are available, which provide solutions according to the flux and vertical height needed at each farm to pump up the water.

The pumps are acquired by the INDAP in relatively great numbers by issuing a call for bids, which facilitates economy of scale. The company that won the bid is in charge of the deployment in rural areas across the country. Between 2012 and 2013, about 1400 PV pumps were installed with a total cost of 3,767,723,586 Chilean pesos (about US\$ 7.5 million) and an installed capacity of $743 \mathrm{~kW}$. The INDAP subsidizes $90 \%$ of the investment 
sum and provides credits to the farmers for the remaining 10\%; amortization is reached within about 4 years (depending on the type of kit and on the energy fuel used before) [84].

The INDAP is a decentralized agency (depending on the Ministry of Agriculture) whose personnel are in close and permanent contact with the farmers and with the GOREs. Therefore, they use to assist farmers to solve simple technical problems at no cost including those related to PV-powered pumps. Only major technical issues are diverted to the pump vender whose contract includes a system checking in the second year of operation [85] and an extended guarantee (3 years for the pump and 5 years for the PV systems; [85]). Indeed, the maintenance of current systems is based on the extended guarantee that includes covering the cost of replacing spare parts.

Although according to an INDAP representative the vast majority of the systems are operative, one challenge may lie in the maintenance once the systems run out of their guarantee as the farmers would have to pay themselves for repairing services and spare parts (so far, no concept has been presented for this case).

\section{Methods}

In order to assess the sustainability of off-grid PV projects in Chilean rural areas, a qualitative document analysis for social sciences was applied (e.g., [10], p. 29). The off-grid PV solutions reviewed in this study included solar home systems (SHS) for residential use, PVpowered water pumps for productive uses, off-grid PV systems for communitarian facilities (health centers and schools), and a micro-grid aimed at both residential and productive uses. These PV-based solutions were compared with previously deployed conventional energy solutions (such as candles/matches, batteries, and diesel generators).

Multiple data sources were assessed for the analysis including regulations, energy policies, and ex-post evaluation reports on electrification programs and projects, as well as the National Energy Agenda (prior and current versions); statistics from the National Energy Commission, the Centre for Innovation and Promotion of Sustainable Energy, and the National Statistics Institute; and scientific papers on related topics. We collected information on the different initiatives, on their evolution, and on their stakeholders. The document analysis also allowed us to identify and select a set of key stakeholders that were interviewed.

Indeed, in addition to the document analysis, we conducted semi-structured interviews with key stakeholders. According to the approach broadly used for the assessment of sustainability (see, for example, [11-15]), the interviewed stakeholders included experts from different
Ministries (Energy, Social Development, Agriculture), NPO activists and project managers, companies' representatives, solar energy lobbyists, and researchers. The method of theoretical sampling was used, i.e., additional interview partners were selected based on the information obtained from the interviewees whom we had initially identified ([10], p. 80). Interviews were finished after saturation (when no additional information could be obtained from further interviews; ([86], p. 168). The interviewed stakeholders (see Table 3 for details) were used to validate the qualitative document analysis and allowed us to fill information gaps.

Interview questions were clustered into four dimensions (institutional, economic, environmental, and sociocultural) considered in this paper and addressed each of the indicators from Table 1. Questions on the institutional dimension comprised, e.g., "What has been the role of this institution for rural electrification in the past and the present?"; "How is the rural electrification process put into practice?"; "How are the community members imbedded in the rural electrification projects?"; and "Who and how is the compliance with the regulation assured?" The economic dimension was addressed

Table 3 Interview partners

\begin{tabular}{|c|c|c|}
\hline Area & Subarea & Division (if applicable) \\
\hline \multirow[t]{3}{*}{$\begin{array}{l}\text { Government institution } \\
\text { energy sector }\end{array}$} & \multirow[t]{2}{*}{ Ministry of Energy } & $\begin{array}{l}\text { Division of Renewable } \\
\text { Energy }\end{array}$ \\
\hline & & $\begin{array}{l}\text { Division of Energy } \\
\text { Access and Equity }\end{array}$ \\
\hline & $\begin{array}{l}\text { Centre for Innovation } \\
\text { and Promotion of } \\
\text { Sustainable Energies } \\
\text { (CIFES) }\end{array}$ & \\
\hline \multirow[t]{3}{*}{$\begin{array}{l}\text { Government institution } \\
\text { non-energy sector }\end{array}$} & $\begin{array}{l}\text { Ministry of Social } \\
\text { Development }\end{array}$ & $\begin{array}{l}\text { Division of Project } \\
\text { Revision and Approval }\end{array}$ \\
\hline & \multirow{2}{*}{$\begin{array}{l}\text { Ministry of } \\
\text { Agriculture }\end{array}$} & $\mathrm{FIA}$ \\
\hline & & INDAP \\
\hline \multirow{4}{*}{$\begin{array}{l}\text { Academics and } \\
\text { research institutes }\end{array}$} & \multirow[t]{3}{*}{ Universities } & Sociologist \\
\hline & & Politician \\
\hline & & RE Project Manager \\
\hline & $\begin{array}{l}\text { Solar Energy Research } \\
\text { Center }\end{array}$ & Project Manager \\
\hline \multirow[t]{2}{*}{ NPOs } & $\begin{array}{l}\text { Solar Energy } \\
\text { Association }\end{array}$ & Lobbyist \\
\hline & $\begin{array}{l}\text { Chilean non-profit } \\
\text { organization }\end{array}$ & RE Project Management \\
\hline \multirow[t]{2}{*}{ Foreign institutions } & $\begin{array}{l}\text { German-Chilean } \\
\text { Chamber of } \\
\text { Commerce }\end{array}$ & \\
\hline & $\begin{array}{l}\text { German Society } \\
\text { for International } \\
\text { Cooperation }\end{array}$ & RE Department \\
\hline Energy companies & $\begin{array}{l}\text { Solar energy } \\
\text { companies (2) }\end{array}$ & Project Managers \\
\hline
\end{tabular}


by questions like the following: "Who is paying for the initial investment/O\&M costs?"; "What has the economic impact been on the user (e.g., energy for productive uses)?"; and "What are the technical minimum requirements for the systems?" The interview covered questions on the environmental dimension such as "How is battery disposal handled in rural electrification?" and "How would you describe the awareness on environmental issues on a political and social basis?" Finally, we asked about socio-cultural issues: "To what extend (and how) are projects adjusted to local circumstances?"; "Have you found different behaviors related to the ethnical background?"; "Do you provide different technological solutions to different communities? If so, what are the criteria these decisions are based on?"; and "Do you remember any cases where PV systems were rejected by a community?" As the interviews were semistructured, in addition to these questions previously defined, we dived much deeper into specific topics by addressing additional topics depending on the background and expertise of the interviewees.

The interviews lasted from 41 to $92 \mathrm{~min}$, and all of them were recorded. Interviews were mostly held in Spanish with the exception of two interviews held in German. The interviewees were of higher hierarchical positions (directors, project managers, leading researchers, and division leaders), as we were interested in the institutional and organizational strategy and the stakeholders' experiences over time.

The assessment of the information gathered by the document analysis and the semi-structured interviews was based on coding. We used the MAXQDA11 ${ }^{\circ}$ software [87], which allowed us to analyze the information and cluster it according to the four dimensions of sustainability considered in this paper.

\section{Results and discussion \\ Institutional sustainability Stability}

The stability (durability) of formal institutions requires a long-term vision. Although institutional stability appears to be less problematic than in its South American neighbors, in Chile as in many DC, short-term thinking is prevalent. This problem does not apply to public employees and formal institutions only but was considered by several interviewees as typical for the Chilean society (i.e., informal institutions). For example, talking about self-consumption PV systems, a manager from a German PV company stated:

here in Chile, I have to say, the time horizon is extremely short. In Chile, PV systems will never have the success that they are having for instance in Germany (...), because people are willing to accept three, four years of amortization only (...). Anything above that is completely out!
A sociologist from a Chilean university argued that short-term thinking could be a consequence of frequent political and economic crises on the continent, which inhibits people to make long-term plans or investments. $\mathrm{He}$ argued that Chile's economy has been stable with high growth rates during the last 25 years but that people's approach of pure survival has nowadays transformed into access to consumption on credit combined with a "here and now" philosophy.

Numerous interviewees also highlighted the widespread neoliberal vision embedded in the state and ultimately in the Chilean society. For example, in our interviews with representatives of the government, they repetitively underlined the importance of technology neutrality, since in their view any form of facilitation or promotion of RE may lead to a market distortion. This neoliberal vision not only constrains the planning role of formal institutions but also restricts the development and enforcement of regulations and standards.

\section{Regulations and standards}

The regulatory framework of the electricity sector in Chile has been considered weak and accounts for a very limited role of the government [88]. In the case of PV systems, the regulatory framework (certification standards and technical regulations) was developed through the GEF/UNDP program "Removal of barriers for rural electrification with NCRE" (see above). However, this regulatory framework is not mandatory in the case of small-scale off-grid projects.

Indeed, we found that local implementations seem particularly vulnerable when the SEREMI of the Ministry of Energy is not involved in the projects and their technical approval is not required. This may be the case when the investment cost of the rural project does not exceed 70 million Chilean pesos (approx. US\$ 120,000). For example, the representative of a private firm that recently won three local public bids for off-grid PV systems stated “(...) there are relatively many municipalities with little idea about what they need, but they know that there are funds or state subsidies for certain PV projects". This may become a great issue, since

there are insufficient minimum standards in the bids, so that you often lead an unwinnable battle, well, that you have a futile situation if you own a good product and of course you want to offer it, but at the same time you have competitors that evidently offer low quality products. Yet, if the person that ultimately takes the decision lacks technical know-how or the background or experience with the products, it will be hard for him to decide. 


\section{Adaptability}

The regulatory framework of projects with a budget greater than 70 million Chilean pesos (approx. US\$ 120,000 ) is notoriously more robust; these projects have formal requirements that even include defining an O\&M model. However, O\&M ultimately depends on either the commitment/organization of the community (operating the systems via a cooperative) or the availability of a private company (operating the systems against a compensation fee). Still, finding a private company interested in the operation of small-scale electrification projects is a challenge in remote areas of the country. Local governments can hardly assume these tasks either. According to a representative of the Ministry of Social Development:

(...) since local governments, since they have many functions, they don't have the technical capacity to operate and maintain (...), at a national scale, this can be solved, but at the scale of small communities, it's not that easy (...). We clash with the issue of not having an agency to operate and maintain [small-scale electrification projects].

The lack of an agency with the responsibility of overseeing off-grid PV systems seems to be a major drawback, which compromises the ability of Chilean institutions to meet O\&M needs and in turn to ensure the sustainability of off-grid PV systems. This weakness in the Chilean institutions is well known in local academic circles. For example, according to a researcher from a Chilean university: "here in Chile there should be a central agency - I even named it "Monitoring Microgrid Unit". This office should indeed focus on doing this kind of management". Yet, the Ministry of Energy has not considered such an agency in the case of the off-grid PV systems.

The successful program for PV-powered water pumps aimed at supporting small and isolated farms (see above) may be an example of the benefits of having a public decentralized agency overseeing off-grid PV systems. Indeed, as described above, the INDAP not only sponsored the deployment of the systems but also offers support on their O\&M, solving small technical problems that the poor farmers could hardly overcome on their own.

\section{Decentralization and openness to participation}

In the case of off-grid systems, the participation of the community has helped to successfully implement some early projects. For example, in the "Coquimbo Project" (see above), according to a representative of the Ministry of Energy, people were involved in the project from the beginning. Indeed, the Ministry of Energy believes that a close collaboration between the community and the project implementer is indispensable for these projects to be sustainable over time. As declared by a DAEE representative, "the most striking success factor for the PV systems is an empowered community who wants the project, accepts it, and understands it".

Unfortunately, a participative approach has not been applied in all off-grid projects. For example, in 2010, several off-grid PV projects were implemented in rural areas in southern Chile, in particular in the Aysén region, one of the 15 Chilean "regions" or territories. When in 2012 an ex-post evaluation was conducted on these projects, it showed that though the off-grid PV systems were appropriately deployed, harming system interventions from users occurred in $18 \%$ of the cases because of a lack of user training (only $44 \%$ of the beneficiaries of a PV system received written instructions for use, and 47\% received some kind of briefing) [89]. A lack of user training and technical know-how was similarly observed in a small town called Curepto in the Maule region (about $300 \mathrm{~km}$ south from Santiago) [90].

\section{Economic sustainability Cost-effectiveness}

In order to be sustainable, a solution for electrification must be cost-effective. Rural electrification costs depend on various factors including population density, local energy resources, the distance from the closest grid, and the level and quality of the energy access [91]. Off-grid PV systems are indeed a cost-effective solution at Chilean locations where the grid expansion is not viable due to geographical conditions or at locations with a high degree of dispersion of the local population [81]. However, according to Chilean officials, fossil fuel solutions such as those based on diesel generators are often deployed at these remote locations.

The problem is that in the past, the chosen technology had often been selected based on the initial costs only (PV systems have high initial costs compared to diesel), without considering, for example, environmental impacts or O\&M costs. Regarding small off-grid systems based on diesel generators deployed in small islands in southern Chile, a project manager explained:

\section{(...) all these projects that have been implemented} they are all diesel, which is ultimately more expensive. So, you are travelling two hours to an island where there are 100 families and you have to bring diesel.

Due to the low O\&M cost of PV-based solutions, the total costs of a diesel generator normally exceed those of a RE system over its lifetime. For instance, in the Aysén region, different technologies were compared in order to electrify 49 families with an energy consumption of around $15 \mathrm{kWh}$ per month [92]. Although the initial 
investment of a 1200-Wp PV system (including logistics, batteries, inverters, and user training) was quite high (236,499,000 Chilean pesos per system, i.e., about US\$ $380,000)$ as compared to a diesel generator $(61,025,000$ Chilean pesos, i.e., about US\$ 98,000), the present value of capital costs was actually lower (at a 6\% discount rate for a 20-year term) for the off-grid PV systems with a value of 473,594,000 Chilean pesos (about US\$ 764.000), than for a diesel generator with 783,498,000 Chilean pesos (about US\$ 1,263,000) [92].

In recent years, it appears that Chilean officials have recognized that off-grid PV systems are a cost-effective solution at remote locations [93]. Indeed, previously deployed diesel generators have recently been substituted by off-grid $\mathrm{RE}$ systems in many projects [82]. Moreover, the new Energy Agenda issued by the Ministry of Energy in 2014 [94] vows to further substitute diesel generators by RE systems and, even more importantly, to consider all costs over the lifetime in the evaluation of rural electrification projects.

\section{Reliability}

The ex-post evaluations of rural electrification projects shown in Table 2 have revealed significant differences in their operational reliability. Whereas in the evaluation reports for the "Coquimbo Project" and some communities from the Maule region all systems from the analyzed projects were found operational [82, 89], Covarrubias et al. [90] and Navarro et al. [95] reported deficiencies and a poor performance of the systems in the inspected projects (Maule, Aysén, Tarapacá, and Coquimbo regions). In fact, even where systems were found operational, Deuman [89] warned that the reliability of the systems was jeopardized, as O\&M ultimately relied on voluntary efforts from the users.

Indeed, the reliability of the off-grid PV systems strongly depends on ensuring O\&M. This explains the high reliability of the micro-grid project in Huatacondo (only one failure between 2010 and 2014), where a very well-organized and trained community facilitated and ensured O\&M [96].

Another factor that jeopardizes the reliability of the systems is that although Chile has a legal system significantly more developed than its South American neighbors, enforcement of contracts with private companies in charge of the operation of small electrification programs has often been problematic. For instance, in Curepto (located in the Maule region), the contract between the company that installed the systems (42 households were electrified with off-grid PV systems) and the local municipality stipulated that the company was in charge of O\&M (including the battery replacement); yet, the company never complied with its duties, such that the system reliability was extremely poor [90]. Moreover,
Navarro et al. [95] found that despite the fact that the contracts between the CNE and the EDCs have a clause that requires the EDC to register all off-grid system defects, the projects had not been followed up upon, which substantiates the lack of enforcement.

In cases where a private company is not available to operate the systems, the technical know-how and skills have to be locally available or transferred to the community in advance. Otherwise, the reliability of the system can be seriously comprised. For example, in the Aysén region (in southern Chile), the ex-post evaluation of the projects (90 off-grid PV systems) that were supposed to be operated by the community via a cooperative showed that the systems were not administered by anyone [89]; spare parts (i.e., bulbs) were not available, such that the users replaced them by poor-quality products; and that funding for O\&M was not available [89]. Although the $\mathrm{CNE}$ requested to the local municipalities to take care of the operation of the systems, this did not occur [97]; the mayors of the municipalities explained that despite their willingness, they had neither the funds nor the technicians to do so [89].

\section{Initial investment}

In the Chilean residential sector, according to a representative of a Solar Energy Association, investments in self-consumption PV systems (that are connected to the grid) have an estimated payback period of 10-12 years. However, the required investment may still not be affordable for most Chilean households. A researcher from a Solar Energy Research Center pointed out that: "...this case [self-consumption PV system] is not for Juanita [name that stands for a mid-income citizen], this is for the Miss who is living in the upper class neighborhood". The unaffordability of self-consumption PV systems is aggravated, by the lack of funding instruments (such as leasing) for private consumers in Chile.

In contrast, the affordability of the initial investment of off-grid PV systems for rural users is not an issue if the project is selected and given preference by the GORE, since it is fully covered by the FNDR or by the sponsoring public agency [3]. In the case of the PVpowered water pumps sponsored by the INDAP, the agency subsidizes $90 \%$ of the initial investment, while the beneficiary pays the remaining $10 \%$ as a long-term loan.

\section{O\&M costs}

In the case of off-grid projects funded by the FNDR/ GORE, the O\&M costs are included in the contracts between the municipalities (that normally sponsor the projects) and the private companies in charge of the O\&M $[78,79]$. Although the users pay for energy consumption, the tariff is hardly enough to cover the O\&M of the 
systems. Since the tariff for off-grid PV systems is unregulated, normally, the tariff per $\mathrm{kWh}$ from the closest community with a grid connection is adopted [78].

For instance, within the "Coquimbo Project" (northern Chile), the monthly charge for the running costs of a 225Wp PV system is 12,326 Chilean pesos (about US\$20), of which the user pays 3000 Chilean pesos (around US\$ 5); the regional government pays for the difference of 9326 Chilean pesos (about US\$ 15) per user [82]. Although since 2009 the subsidies needed to cover these differences can also be requested to the respective GORE (see Resolution No. 137), they must be evaluated and approved each year by the respective SUBDERE. The need of annual approval causes uncertainty, since the subsidy is not guaranteed for the entire lifetime of the project. According to a representative of the Ministry of Social Development, O\&M costs are not considered as relevant as the initial investment in the case of off-grid projects:

In Chile, the public sector $(. .$.$) is very concerned$ about taking care of the investment processes, investment in capital. But this process, which is O\&M, isn't so, so important. (...) So, good evaluation and investment analysis are made, but after that, there isn't much interest for this to have a permanent expenditure.

A researcher from the Solar Energy Research Center confirmed that the budget allocation focused mainly on the initial investment is also common in the case of projects funded by donations from the private sector:

(...) they [private companies and the government] can give great support to the initial investment. They will fund the system. But those who support the development are not very interested afterwards to be in charge of the maintenance and all that, because it is a headache, and they say 'I don't want to continue with all these things. I support you with the construction, but I don't want to get involved in this infinite thing'.

Although the low O\&M cost of PV technologies should favor the deployment of PV solutions, decisions have often been made only considering the cost of the initial investment (which tends to favor fossil fuel technologies such as those based on diesel generators). As further discussed in the "Institutional sustainability" section, this behavior may be related to the short-term thinking prevalent in the Chilean society and the governmental agencies.

\section{Contributions to income of users}

The program of PV-powered water pumps promoted by the INDAP showed that in Chile off-grid PV projects for productive uses can succeed. Indeed, an ex-post study conducted by GreenLab (2012) estimates that the substitution of the diesel pumps by off-grid PV water pumps generates a net benefit of between 57 and 68 million Chilean pesos (US\$ 92,000 to US\$ 110,000) per project. As explained by a representative of the Foundation for Agrarian Innovation (FIA by its Spanish acronym):

In the case of the farmers, who are business people after all, because agriculture is a business. If you present to them, 'look, pumping with grid electricity will cost you this, and pumping with a PV panel will cost you that', they will take it.

According to an INDAP representative, considering the short payback period (of about 4 years), farmers with higher spending capacities than those who received PVpowered water pumps from the INDAP bought the PV pumps on their own account. Contrary to the residential electrification project, farmers made this investment decision as they could decide on the technology, thus taking the entire costs (initial investment plus O\&M) in their technology choice into consideration.

Beyond the water pump program, several other RE projects for productive uses have been implemented in Chile. For instance, the FIA funded demonstration systems of PV-powered purification and desalinization of water, PV-powered greenhouses, PV-powered irrigation, and a joint program with Information and Communication Technology (TIC by its Spanish acronym) using PV-powered antennas that allowed Internet connections in rural areas. However, all of these solutions are only pilot projects so far.

\section{Environmental sustainability \\ Environmental awareness}

In 2010, the creation of the Chilean Ministry of Environment and the Service for Environmental Evaluation (SEA by its Spanish acronym) showed the country's increased environmental awareness. Environmental policies like the carbon tax of US\$ 5 per ton of carbon dioxide $\left(\mathrm{CO}_{2}\right)$ (starting from 2018) have thereinafter been approved (Law 20.780). Moreover, in its Intended Nationally Determined Contribution (INDC) declaration for the COP21 in Paris, Chile committed to reduce its $\mathrm{CO}_{2}$ per GDP unit by $30 \%$ by 2030 compared to 2007 . However, this reduction may be insufficient, as due to the expected GDP growth, GHG emissions would be 222\% above 1990 and 75\% above 2010 levels (calculations were based on the medium-case GDP projections of the Chilean government) [98]. The Ministry of Environment had presented two more ambitious proposals (option A 40-45\% and option B 35-40\% reduction of GHG by 2030; [99]), but they were ultimately not 
considered by the central administration. Indeed, several interviewees pointed to the limited role of this Ministry of Environment in the national policy, which is also reflected in the small budget allocated to this Ministry (about $0.13 \%$ of the total national budget in 2014 [100]).

The Ministry of Energy in turn has so far maintained its (previously mentioned) policy of technological neutrality in the energy sector, which is also reflected in the energy matrix: In the case of the SING systems, carbon and gas currently account for 48.9 and $36.5 \%$ of the total electricity generation, respectively, whereas fuel oil and diesel contribute about $4 \%$ each [101]. In the case of the SIC system, hydro energy makes up almost $40 \%$ of the energy share, followed by diesel (21.2\%), natural gas (11.5\%), carbon (10.4\%), and carbon petroleum coke (3.6\%) [101].

Several interviewees confirmed a higher awareness on environmental issues, especially of the younger population. This has recently led to social movements, which successfully stopped several energy generation projects (e.g., HidroAysén, Alto Maipo, Castilla, Punta Acalde) [102-105]. However, according to a social scientist, these movements seem to be mainly motivated by concerns about potential negative effects on the local communities (for example, direct pollution), and often, they also tend to embrace a form of "technology neutrality". This means that communities can reject any form of the energy generation regardless of the type of technology (fossil fuel or renewable), if they are directly affected. A representative of the German-Chilean Chamber of Commerce explained that: “(...) if somewhere far away, $500 \mathrm{~km}$ towards the sea there is a coal-fired power plant, they don't care. But if there is a little power plant in their backyard, although renewable, then they might now get bothered". From the Chilean perspective, concerns on global problems such as climate change seem to be distant.

\section{Environmental impacts}

In the case of off-grid rural electrification projects funded by the FNDR/GORE, the selection criteria for a technology are exclusively based on direct costs, such that environmental impacts due to direct pollution or GHG emissions are not considered in the project evaluation process. Furthermore, although rural off-grid PV systems have a much lower environmental impact than, e.g., diesel generators, the battery disposal may become a major issue in rural communities. However, we were unable to find any functionary involved in off-grid PV projects funded either by the FNDR/GORE or by municipalities aware of the battery disposal norms established during the CNE/UNDP program.

\section{Socio-cultural sustainability \\ Accessibility (disparity/equity)}

In Chile, major efforts on electrification during the last 20 years have led to a remarkable electrification rate (about $99 \%$ of urban and $97.3 \%$ of rural households are electrified [3]). These sustained efforts have shown the broad political consensus on the necessity of providing electricity to all. However, figures show significant differences in the electrification rate between different groups. For example, $1.62 \%$ of the extreme poor have no access to electricity, as opposed to 0.35 of the non-poor [63]. Moreover, as shown in Fig. 1, there is also a discrimination against indigenous people.

Moreover, for those who do have access, there is a high divergence of electricity prices between regions.

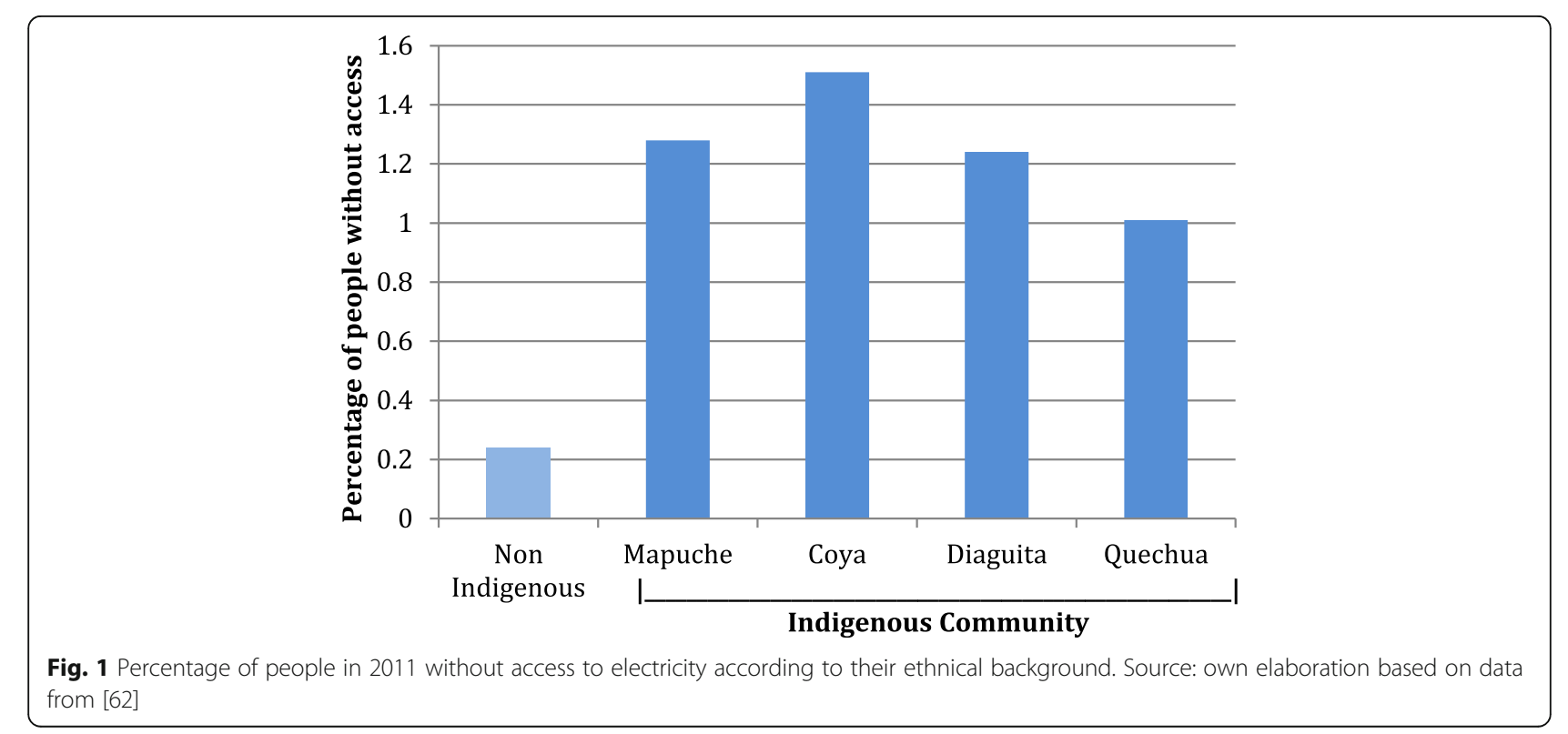


This is due to the fact that in Chile electricity tariffs for regulated consumers (including residential users) reflect the real costs of energy generation, transmission, and distribution. Differences in tariffs may diverge by a factor of 2.3 between one community and another [106]. As a consequence, whereas the poorest quintile (often from rural areas where distribution costs are higher and electricity is therefore more expensive) spent about $8.25 \%$ of their income on electricity (though consuming much less), the portion of the richest quintile accounted for $3.47 \%$ only [107]. Recently (June 2016), the National Congress approved a law on "tariff equity", a sort of cross-subsidy mechanism that will be funded by customers with a monthly consumption above $200 \mathrm{kWh}$; the law stipulates that residential electricity tariffs may not diverge by more than $10 \%$ between regions [108].

In addition to differences in tariffs, the amount of energy supplied by the off-grid systems may also differ between projects and regions. No protocols have been defined regarding the capacity or the amount of energy supplied by the off-grid systems. Part of the problem is that there is no updated information on the energy consumption per household in rural areas. This has led to complains of some users, as a low energy supply was provided to some communities, while a somewhat higher supply was provided to others (e.g., sufficient capacity for a fridge). For instance, in Aysén (southern Chile), a community insisted in a higher PV system capacity than initially planned. According to a representative of the Ministry of Energy, these complains led to a discussion on disparity/equity: "we [the Ministry of Energy] had a conflict, we said, gosh, how are we going to fund [electricity for] a fridge if we didn't do it before [in other projects]?"

As opposed to the grid, off-grid PV systems cannot provide more energy in response to a changing demand, as they are limited to the initially installed capacity. A DAEE representative acknowledged that although households count as electrified in the statistics, basic needs such as a refrigerator are usually not met with the current PV systems, as projects were designed based on budget constraints. For instance, Covarrubias et al. [90] found that the system on average only provided electricity for 1-1.5 h (never more than $4 \mathrm{~h}$ ) per day.

Being aware of this issue, the DAEE is currently working on a new definition of electrification, and "based on this definition that we are working on, we are trying to convince the Minister [of Energy], we say that certain systems were pre-electrification, and now we will do a second phase, which is electrification". Therefore, the currently installed energy system will need to be either substituted or upgraded to meet an increasing energy demand.
The Ministry of Energy is also currently switching its strategy from an electrification approach to an integral "energization" approach, which goes beyond basic household electrifications and aims to cover all energy needs of the communities. The DAEE was created precisely to tackle this problem, as explained by its representative: "...[t]he concept of equity for us is a concept that ... if the State provides different services, we should all have the same service quality everywhere". According to the energy roadmap from the Ministry, one of the first steps in the application of the "energization" approach is to assess the necessities of vulnerable groups, which is expected to occur from 2016 to 2018.

\section{Social acceptance}

The civil society has recently played a significant role in the Chilean energy sector. In response to disagreements and discontent with several energy projects (mainly hydroelectric and coal-fired power plants), social movements have emerged [88]. Protesters claim to be consulted and involved in the projects; otherwise, they have shown to have the power to stop them. As revealed by a representative of the German Chamber of Commerce, this was for instance the case with a German firm that had been working on a PV project for 3 years. Since the firm did not engage the local community and their elected local authorities, residents of the community with the support of their mayor sued the company. According to the representative of the German Chamber of Commerce, they managed to stop the project despite the fact that the company had complied with all formal and legal requirements. As discussed elsewhere [88, 102], efforts for engaging the community have not been addressed properly in Chile, as participation is still understood as the provision of information, rather than the engagement of the community from cradle to grave.

According to several interviewees, the off-grid PV systems have also experienced rejection from communities in rural areas. These cases mainly involved indigenous communities in southern Chile. A DAEE representative recalls:

They [the community] prefer to wait two years to obtain the resources, such that they put them the grid. It was like that; we already had the project ready. The party leader came here to the Ministry, and said 'listen, sweetheart, your study is really great, but my people don't want this. [...] We will talk to the distribution company. It's either grid or grid.'

According to the Ministry of Social Development, the negative experience with off-grid PV systems (including the limited capacity installed) that inhabitants of rural areas observed in the neighboring villages in the past 
may have aggravated the premature rejection of the systems. An NPO member has proposed identifying important social actors within a community to rely on, who also have the status, the skills, and the motivation to engage and involve the community.

Nevertheless, there are successful experiences in gaining social acceptance of off-grid PV project. In the Huatacondo project, for example, the community was previously characterized by a multidisciplinary team of specialists including anthropologists, sociologists, and legal scholars, who defined social interactions of the community and their use of the resources, identified key participants, and analyzed the disposition of the users to participate in the project and define their roles [109]. As a consequence, most users accepted and advocated the project, as $73 \%$ considered that the project had a positive effect on their everyday life [96].

\section{Accuracy}

In order for a project to be accurate, it has to meet the specific local needs and consider the socio-cultural reality of each community. The Ministry of Energy seems to be aware of the need of accuracy. Accordingly, the staff from the DAEE is trained on the bottom-up energy model "HOMER", an optimization model aimed at remote areas that evaluates micro power on-grid and offgrid systems to determine the configuration of the most appropriate solution for a particular community [110]. Yet, when the Ministry of Energy is not involved in the selection process (in the case of projects of less than approx. US\$ 120,000), the municipality is entitled to decide which technology will be deployed (usually without having the required know-how on energy models or on technological options). This lack of know-how can become problematic, since the municipality may have to trust in a provider whose opinion may be biased. A representative of the Ministry of Energy recalled a conversation with a local energy provider of PV systems who was trying to sell his product to the Municipality:

'Listen, I [the provider] can put PV panels for 100 houses.' And it turns out that all these houses are contiguous, and you have a river with a waterfall and you say 'no, no, no, wait. Let's see. Here it's better to build a mini hydro station, you have much more energy, it's cheaper, and more sustainable over time, etc.'

Inaccurate systems tend to underestimate the required capacity: For instance, as the system capacity of $150 \mathrm{Wp}$ was too small in Curepto (providing on average 1.5-2 $\mathrm{h}$ of electricity), people had to continue using their alternative energy sources such as candles, batteries for lanterns and radios, and paraffin. Hence, on average, they spend an additional US\$ 6.3 per month [90]. This deficiency has been explained by the fact that the PER program exclusively focused on reaching the target electrification rate instead of assuring the quality of the service/technology [95]. A review of the BIP database shows that some recent projects have corrected this flaw by upgrading the capacity of SHS, e.g., to $480 \mathrm{Wp}$ in Curanilahue (Maule region); $600 \mathrm{Wp}$ in Los Torreones, Lago Zenteno, and Litoral (in the Aysén region); and $500 \mathrm{Wp}$ in Tortel, O'Higgins, and Cochrane (also in the Aysén region) [111]. In other projects, however, the capacity remains low until today (e.g., SHS of 100 and $130 \mathrm{Wp}$ in the Coquimbo region in 2012 and $85 \mathrm{Wp}$ in the Arica and Parinacota region in 2009) [111].

\section{Socio-cultural justice}

Interviewees from universities, NPOs, and the Ministry of Energy all agreed on the importance of engaging small communities and respecting their culture. However, they also pointed out the fact that there is no universal solution (i.e., an engagement model) for all communities, mainly because of the diversity of small communities inhabiting rural areas in Chile. As summarized by a researcher from a Chilean University:

It strongly depends e.g. how the community is organized, if it is a united social structure, how decisions are taken within a community, the vision they have about the systems. Many things. How organized they are. [...] and based on all that, one can propose -as we are doing as a university- the management scheme that best adapts to this reality.

Therefore, the major issue is not necessarily the lack of awareness on the cultural particularities of small communities but the lack of an engagement model. This has been particularly problematic in the case of large-scale energy projects (such as hydropower plants) (see [88]).

Regarding each sustainability indicator considered in this paper, Table 4 provides a summary of the strengths and weaknesses of rural electrification efforts in Chile based on off-grid PV solutions.

\section{Conclusions}

This paper analyzes the sustainability of rural electrification efforts in Chile paying special attention to off-grid PV programs. Our assessment was based on a set of indicators (Table 1) corresponding to the four dimensions of sustainability considered in this paper: institutional, economic, environmental, and socio-cultural.

Institutional sustainability demands for stability/durability. Although institutional stability appears to be less problematic than in its South American neighbors, the widespread neoliberal vision embedded to the Chilean 
Table 4 Strengths and weaknesses of rural electrification efforts in Chile based on off-grid PV solutions

\begin{tabular}{|c|c|c|}
\hline Indicator & Strengths & Weaknesses \\
\hline Stability & $\begin{array}{l}\text { Formal institutions are stable in Chile compared to its Latin } \\
\text { American neighbors. }\end{array}$ & \\
\hline $\begin{array}{l}\text { Regulation and } \\
\text { standards }\end{array}$ & $\begin{array}{l}\text { Technical standards and regulations for PV systems have been } \\
\text { defined (GEF/UNDP program). }\end{array}$ & $\begin{array}{l}\text { Standards not mandatory and not necessarily used in } \\
\text { tenders. }\end{array}$ \\
\hline \multirow{2}{*}{$\begin{array}{l}\text { Decentralization and } \\
\text { openness to } \\
\text { participation }\end{array}$} & \multirow[t]{3}{*}{$\begin{array}{l}\text { Engagement of communities, in some projects, for example, in } \\
\text { the case of the Coquimbo and Huatacondo projects. }\end{array}$} & $\begin{array}{l}\text { Lack of (technical) know-how in rural areas (which has } \\
\text { affected some PER projects). }\end{array}$ \\
\hline & & $\begin{array}{l}\text { Participation is still understood as the provision of } \\
\text { information, rather than the engagement of the community } \\
\text { from cradle to grave. }\end{array}$ \\
\hline Adaptability & & $\begin{array}{l}\text { Chile lacks a decentralized agency for overseeing off-grid } \\
\text { electrification projects. }\end{array}$ \\
\hline Affordability & Initial investment is covered by the FNDR. & $\begin{array}{l}\text { No cross-subsidies aimed at covering off-grid costs (from } \\
\text { users connected to the grid, for example). }\end{array}$ \\
\hline Cost-effectiveness & $\begin{array}{l}\text { The new Energy Agenda considers the substitution of projects } \\
\text { based on diesel generators for cost-effective solutions based on } \\
\text { PV. }\end{array}$ & $\begin{array}{l}\text { Decisions have been made based on the initial costs only, } \\
\text { not considering O\&M costs or environmental impacts (life- } \\
\text { cycle costs). }\end{array}$ \\
\hline $\begin{array}{l}\text { Consideration of } \\
\text { O\&M costs }\end{array}$ & & $\begin{array}{l}\text { The costs for O\&M of PER-sponsored projects have to be } \\
\text { annually approved by the SUBDERE (thus causing } \\
\text { uncertainties). }\end{array}$ \\
\hline $\begin{array}{l}\text { Contribution to } \\
\text { income of users }\end{array}$ & $\begin{array}{l}\text { PV programs for productive use (such as those sponsored by the } \\
\text { INDAP) widespread. }\end{array}$ & \\
\hline Reliability of supply & $\begin{array}{l}\text { Ex-post project evaluations found that most of the systems of } \\
\text { the PER program were operational. }\end{array}$ & $\begin{array}{l}\text { Reliability depends on the engagement/proactivity and } \\
\text { technical skills of the community, which may threaten the } \\
\text { sustainability of these projects. }\end{array}$ \\
\hline $\begin{array}{l}\text { Environmental } \\
\text { awareness }\end{array}$ & $\begin{array}{l}\text { The younger population exhibits higher awareness on } \\
\text { environmental issues. }\end{array}$ & $\begin{array}{l}\text { Selection criteria for a technology are still exclusively based } \\
\text { on direct costs without considering the environmental } \\
\text { impacts. }\end{array}$ \\
\hline $\begin{array}{l}\text { Environmental } \\
\text { impact }\end{array}$ & $\begin{array}{l}\text { GEF/UNDP environmental standards for disposal have been } \\
\text { established. }\end{array}$ & $\begin{array}{l}\text { As environmental standards are not mandatory, battery } \\
\text { disposal is often not considered in the projects. }\end{array}$ \\
\hline $\begin{array}{l}\text { Accessibility } \\
\text { (disparity, equity) }\end{array}$ & High electrification rate in Chile ( $99 \%$ national; $97 \%$ rural). & $\begin{array}{l}\text { Indigenous communities still have less access to electricity, } \\
\text { since communities have to request electrification at first } \\
\text { place. This approach favors better organized communities } \\
\text { leaving behind others-normally the poorest indigenous } \\
\text { communities. }\end{array}$ \\
\hline $\begin{array}{l}\text { Social acceptance } \\
\text { (accuracy) }\end{array}$ & $\begin{array}{l}\text { System size has been upgraded in many local projects. Training } \\
\text { on the energy model HOMER for staff of the Ministry of Energy. }\end{array}$ & $\begin{array}{l}\text { As no minimum capacity is defined, inaccurate solutions } \\
\text { often lead the rejection of off-grid PV systems. }\end{array}$ \\
\hline Cultural justice & $\begin{array}{l}\text { Chilean officials are aware of the importance of local } \\
\text { participation. Indeed, cultural factors (gender, ethnical } \\
\text { background, roles within a community) are considered in the } \\
\text { programs. }\end{array}$ & \\
\hline
\end{tabular}

society appears to be constraining the role of formal institutions and restricting the development and enforcement of regulations and standards. In fact, although a regulatory framework for rural electrification with $\mathrm{RE}$ exists, it is not mandatory.

The lack of a mandatory set of regulations and standards makes the implementations of small-scale off-grid projects unreliable. This is the case of projects whose investment cost does not exceed 70 million Chilean pesos (approx. US\$ 120,000) that can be funded by municipalities or local authorities without the prior technical approval of the Ministry of Energy. Greater projects with public funding require the revision of the Ministry of Energy, which even includes defining an O\&M model.
However, O\&M has shown to be a challenge in remote areas of the country due to the fact that private companies are not interested in the operation of small-scale electrification projects. Having a public decentralized agency overseeing off-grid PV systems in the country may address this drawback, but the Ministry of Energy has not yet considered such a solution.

Economic sustainability of electrification solutions requires ensuring the funding of the systems. The affordability of the initial investment in the case of off-grid PV systems for rural users is not an issue in Chile, since it is fully covered by the FNDR or by the sponsoring public agency. However, the cost of the O\&M, which can hardly be afforded by the largely poor inhabitants of 
remote areas of the country, is funded neither by the FNDR nor by the private sponsors. Although the O\&M costs can also be requested to the respective GORE, they must be evaluated and approved every year. The need of annual approval causes uncertainty and leads to unreliable systems, since the subsidy is not guaranteed for the entire lifetime of the project.

Economic sustainability also requires providing a costeffective solution for electrification. Though the Ministry of Energy favors cost-effective solutions for rural electrification, they have been making decisions based on the initial costs only, without considering for example O\&M costs or environmental impacts. This situation has recently improved, and the new Energy Agenda vows to consider all costs over the lifetime in the evaluation of rural electrification projects.

Some programs, such as the PV-powered water pumps promoted by the INDAP (an agency that depends on the Ministry of Agriculture), have successfully contributed to the income of users. Although most of these programs were only pilot projects, they have showed the potential of off-grid PV projects for productive uses in Chile. Indeed, favored by the unique conditions of its northern and central territory, the adoption of solar energy technologies would yield substantial benefits for the poor inhabitants of rural areas of the country. However, exploiting the solar potential of the country will require a better coordination between different ministries (such as Energy, Agriculture, and Economy, Promotion, and Tourism).

Environmental sustainability entails the prevention of negative environmental impacts, which in turn requires a widespread environmental awareness. Although especially the younger population exhibits a higher awareness on environmental issues, these movements seem to be mainly motivated by concerns on potential negative effects on the local communities (for example, direct pollution). From the Chilean perspective, concerns on global problems such as climate change seem to be distant. Moreover, the selection criteria for a technology in off-grid rural electrification projects funded by the FNDR/GORE are still exclusively based on economical factors. Environmental impacts due to direct pollution or GHG emissions are not considered in the project evaluation process. Improvements regarding the impact assessment, and also in environmental awareness and understanding, are required for ensuring the environmental sustainability of rural electrification efforts.

Although Chile has conducted remarkable efforts on electrification during the last 20 years, current figures show that the poor and indigenous communities have less access to electricity than non-poor and nonindigenous communities. This disparity is a major drawback that underscores the need for adjusting the bottom-up approach (which means that the communities or the local authorities have to request electrification at first place) adopted by the Ministry of Energy in rural electrification. Indeed, this approach favors better organized communities leaving behind others-normally the poorest. The bottom-up approach in rural electrification fails to meet equity criteria, significantly compromising the socio-cultural sustainability of rural electrification efforts in Chile.

In the case of projects targeting indigenous communities, social acceptance of some off-grid PV solutions has been problematic. The rejection of some communities to off-grid PV solutions has often been due to their lack of accuracy (as the provided solution was unable to meet the specific local needs). Ultimately, the rejection may be linked with the lack of an engagement model. Indeed, in Chile, participation is still understood as the provision of information, rather than the engagement of the community from cradle to grave. Progress regarding accuracy is needed for ensuring the socio-cultural sustainability of rural electrification efforts in Chile.

Yet, the formal institutions in Chile (in particular, the Ministry of Energy) are making progress and have learnt important lessons from flaws in previous rural electrification programs. Indeed, the new policy of the Ministry of Energy includes considering the life-cycle costs in the valuation of projects, shifting from a pre-electrification approach with low PV system capacities to an "energization" approach, fostering the productive use of energy, and adopting cross-subsidies aimed at improving equity in energy prices.

\section{Abbreviations}

BIP: Integrated Project Database; CC: Climate change; CER: Centre for Renewable Energy; CIFES: Centre for Innovation and Promotion of Sustainable Energy; CNE: National Energy Commission; $\mathrm{CO}_{2}$ : Carbon dioxide; CONAFE: National Electrical Force Company; CORE: Regional council; DAEE: Department of Energy Access and Equity; DC: Developing countries; EDCs: Electricity distribution companies; FDI: Foreign direct investments; FIA: Foundation for Agrarian Innovation; FNDR: National Development Fund; GEF: Global Environmental Facility; GHG: Greenhouse gases; GORE: Regional government; INDAP: Agency for Agrarian Development; INDC: Intended Nationally Determined Contribution; INN: National Institute of Normalization; NCRE: Non-Conventional Renewable Energy; NPO: Non-profit organization; O\&M: Operation and maintenance; OECD: Organisation for Economic Cooperation and Development; PER: National Program for Rural Electrification; PERYS: National Program on Rural and Social Energy; PV: Photovoltaic; RE: Renewable energy; SEA: Service for Environmental Evaluation; SEC: Electricity and Fuel Authority; SEREMIs: Regional Secretaries of the Ministries; SIC: Central Interconnected System; SING: Northern Interconnected System; SUBDERE: Subsecretary of Regional Development and Administration; TIC: Information and Communication Technology; UNDP: United Nations Development Programme

\section{Acknowledgements}

The support of CORFO (Preis 14BPC4-28651, 15BP-45364, and 16BPE2-66227), CONICYT-ANILLO ACT1410, and FONDECYT (Preis 1151034) is gratefully acknowledged. 


\section{Authors' contributions}

SF conceptualized and structured the paper. SF was solely responsible for the data collection (interviews) and analysis. The whole paper was jointly drafted and developed by the authors to bring to the current state. All authors read and approved the final manuscript.

\section{Competing interests}

The authors declare that they have no competing interests.

\section{Author details}

'Leuphana University Lüneburg, Scharnhorststraße 1, 21335 Lüneburg, Germany. ${ }^{2}$ Universidad Santiago de Chile, Avenida Bernardo O'Higgins 3363, Santiago de Chile, Chile.

Received: 5 July 2016 Accepted: 19 October 2016 Published online: 14 November 2016

\section{References}

1. United Nations (UN) (2012) Sustainable energy for all. A framework for action. The Secretary-General's High-level Group on Sustainable Energy for All

2. International Energy Agency (IEA) (2015) World energy outlook. Electricity access database., Available at: http://www.worldenergyoutlook.org/ resources/energydevelopment/energyaccessdatabase/ Accessed on 16 Dec 2015

3. Argomedo R (2015) Financiamiento Estatal en Chile. Programa Electrificación Rural (PER) Workshop on Energy Storage for Sustainable Development April 16-17 2015, Rio de Janeiro. (in Spanish)

4. Ministerio de Energia (2010) Cobertura de Electrificación Rural a Diciembre de 2010., Available at: http://antiguo.minenergia.cl/minwww/opencms/04 Programas/PER/estadisticas.html Accessed on 25 July 2014. (in Spanish)

5. Estay C (2014) Electrificación Rural: Objetivos e Instrumentos para su Desarrollo (Chile)., IV Seminario Latinoamericano y del Caribe de Electricidad, (in Spanish)

6. Cordero RR, Damiani A, Seckmeyer G, Jorquera J, Caballero M, Rowe P, Ferrer J, Mubarak R, Carrasco J, Rondanelli R, Matus M, Laroze D (2016) The solar spectrum in the Atacama Desert. Sci Rep 6:22457

7. Rondanelli R, Molina A, Falvey M (2015) The Atacama surface solar maximum. Bull Am Meteorol Soc 96:405-418

8. Escobar RA et al (2014) Solar energy resource assessment in Chile: satellite estimation and ground station measurements. Renew Energy 71:324-332

9. Centro para la Inovacion y Fomento de las Anergias Sustentables (CIFES) (NA). Reportes CIFES. Available at: http://www.energia.gob.cl/sobre-elministerio/organismos-relacionados/. Accessed on 25 Oct 2016 (in Spanish)

10. Ritchie J, Spencer L. Qualitative data analysis for applied policy research. In Bryman A, Burgess R, eds. Analysing qualitative data. London: Routledge, 1993;173-94

11. Bernhardt J. The effectiveness of science-policy interactions: case studies on climate change mitigation and sustainable development in pan-European forest research and politics. 2015. Doctoral Thesis, University of Hamburg, Hamburg, Germany. Available online: http://ediss.sub.uni-hamburg.de/ volltexte/2015/7160/. Accessed 24 Mar 2015

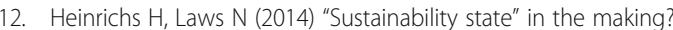
Institutionalization of sustainability in German federal policy making Sustainability 6:2623-2641

13. Nguyen-Trinh HA, Ha-Duong M (2015) Perspective of CO2 capture \& storage (CCS) development in Vietnam: results from expert interviews. Int J Greenh Gas Control 37:220-227

14. Hugé J, Mukherjee N, Fertel C, Waaub JP, Block T, Waas T, Dahdouh-Guebas $F$ (2015) Conceptualizing the effectiveness of sustainability assessment in development cooperation. Sustainability 7:5735-5751

15. Feron S, Heinrichs H, Cordero RR (2016) Are the rural electrification efforts in the Ecuadorian Amazon sustainable? Sustainability 8(5):443

16. Derakhshan, F. (2011). On Sustainability in Local Energy Planning. Lund University. ISBN: 978-91-7473-110-1. Available at: http://lup.lub.lu.se/search/ record/1939379. Accessed on 25 Oct 2016

17. Pfahl S (2005) Institutional sustainability. Int J Sustain Dev 8(1-2):80-96

18. Burford G, Hoover E, Velasco I, Janoušková S, Jimenez A, Piggot G, Harder MK (2013) Bringing the "missing pillar" into sustainable development goals: towards intersubjective values-based indicators. Sustainability 5(7):3035-3059
19. Sharma T, Balachandra P (2015) Benchmarking sustainability of Indian electricity system: an indicator approach. Appl Energy 142:206-220

20. Ilskog E, Kjellström B (2008) And then they lived sustainably ever after?-assessment of rural electrification cases by means of indicators. Energy Policy 36(7):2674-2684

21. Bazilian M, Nakhooda S, Van de Graaf T (2014) Energy governance and poverty. Energy Res Social Sci 1:217-225

22. Wimmler C, Hejazi G, de Oliveira Fernandes E, Moreira C, Connors S (2015) Multi-criteria decision support methods for renewable energy systems on islands. J Clean Energy Technol, 3:185-195

23. Reddy BS (2015) Measuring and evaluating energy security and sustainability: a case study of India

24. Lyndrup M, Jensen TYHW (2012) Illuminating the potential for a rural energy service company-meeting the off-grid electrification challenge in Mozambique (Doctoral dissertation)

25. García VG, Bartolomé MM (2010) Rural electrification systems based on renewable energy: the social dimensions of an innovative technology. Technol Soc 2010(32):303-311

26. Worldbank (2008) Policy and governance framework for off-grid rural electrification with renewable energy sources (TF090884)., Available online: https:/openknowledge.worldbank.org/bitstream/handle/10986/7954/ 683390ESWOWHITOlectrificationOFinal.txt?sequence=2/. Accessed 24 Aug 2015)

27. White W, Lunnan A, Nybakk E, Kulisic B (2013) The role of governments in renewable energy: the importance of policy consistency. Biomass Bioenergy 57:97-105

28. Dunmade I (2002) Indicators of sustainability: assessing the suitability of a foreign technology for a developing economy. Technol Soc 24(4):461-471

29. Brent AC, Rogers DE (2010) Renewable rural electrification: sustainability assessment of mini-hybrid off-grid technological systems in the African context. Renew Energy 35(1):257-265

30. Ilskog E (2008) Rural electrification sustainability indicators: manual for field workers

31. Retnanestri M (2007) The I3A framework-enhancing the sustainability of off-grid photovoltaic energy service delivery in Indonesia. University of New South Wales (UNSW): PhD thesis. OpenURL.

32. Ribeiro F, Ferreira P, Araújo M (2011) The inclusion of social aspects in power planning. Renew Sust Energ Rev 15(9):4361-4369

33. Winkler $\mathrm{H}$, Simões AF, La Rovere EL, Alam M, Rahman A, Mwakasonda S (2011) Access and affordability of electricity in developing countries. World Dev 39(6):1037-1050

34. Holland R, Perera L, Sanchez T, Wilkinson R (2006) Decentralised rural electrification: the critical success factors. Experience of ITDG (Intermediate Technology Developmental Group)

35. Wüstenhagen R, Wolsink M, Bürer MJ (2007) Social acceptance of renewable energy innovation: an introduction to the concept. Energy Policy 35(5): 2683-2691

36. Rondinelli DA, Mc Cullough JS, Johnson RW (1989) Analysing decentralization policies in developing countries: a political-economy framework. Dev Change 20:57-87, Jg., Nr. 1, S

37. Breyer C, Werner C, Rolland S, Adelmann P (2011) Off-grid photovoltaic applications in regions of low electrification: high demand, fast financial amortization and large market potential., pp 5-9

38. Rosen MA (2009) Energy sustainability: a pragmatic approach and illustrations. Sustainability 1:55-80

39. Bhattacharyya SC (2012) Energy access programmes and sustainable development: a critical review and analysis. Energy Sustainable Dev 16(3):260-271

40. Frame D, Tembo K, Dolan MJ, Strachan SM, Ault GW (2011) A community based approach for sustainable off-grid PV systems in developing countries, IEEE. Power and Energy Society General Meeting PESGM, New York: IEEE. pp. 1-7

41. International Atomic Energy Agency (IAEA), United Nations Department of Economic and Social Affairs (UNDESA), International Energy Agency (IEA), Eurostat, European Environment Agency (EEA) (2005) Energy indicators for sustainable development: methodologies and guidelines. International Atomic Energy Agency (IAEA), Vienna

42. Prandecki K (2014) Theoretical aspects of sustainable energy. Energy Environ Eng 2(4):83-90. doi:10.13189/eee.2014.020401

43. Pereira MG, Freitas MAV, da Silva NF (2010) Rural electrification and energy poverty: empirical evidences from Brazil. Renew Sust Energ Rev 14(4):1229-1240

44. Vera IA, Langlois LM, Rogner HH, Jalal Al, Toth FL (2005) Indicators for sustainable energy development: an initiative by the International Atomic 
Energy Agency. In: Natural Resources Forum, Vol. 29. Blackwell Publishing Ltd. Oxford, UK No. 4, pp. 274-283

45. Cook P (2011) Infrastructure, rural electrification and development. Energy Sustainable Dev 15(3):304-313

46. De Soysa I, Jütting J (2006) Informal institutions and development-what do we know and what can we do?. OECD Development Center, International Seminar, Paris

47. Demirtas O (2013) Evaluating the best renewable energy technology for sustainable energy planning. Int J Energy Econ Policy 3:23-33

48. Mainali B, Pachauri S, Rao ND, Silveira S (2014) Assessing rural energy sustainability in developing countries. Energy Sustainable Dev 19:15-28

49. Jacquin P, Ortiz B, Vallve X (2011) Social, economic and organizational framework for sustainable operation of PV hybrid systems within mini-grids, Report IEA-PVPS T11-05, 2011

50. United Nations (2005) The energy challenge for achieving the millennium development goals., Available at: http:/www.undp.org/content/undp/en/home/ libranypage/environment-energy/sustainable_energy/the_energy_challenge forachievingthemillenniumdevelopmentgoals.html Accessed on 16 Aug 2015

51. Axelsson R, Angelstam P, Degerman E, Teitelbaum S, Andersson K, Elbakidze M, Drotz MK (2013) Social and cultural sustainability: criteria, indicators, verifier variables for measurement and maps for visualization to support planning. Ambio 42(2):215-228

52. Hirmer S, Cruickshank H (2014) The user-value of rural electrification: an analysis and adoption of existing models and theories. Renew Sust Energ Rev 34:145-154

53. Müggenburg H, Tillmans A, Schweizer-Ries P, Raabe T, Adelmann P (2012) Social acceptance of PicoPV systems as a means of rural electrification-a socio-technical case study in Ethiopia. Energy Sustainable Dev 16(1):90-97

54. Fenner RA, Ainger CM, Cruickshank HJ, Guthrie PM (2006) Widening engineering horizons: addressing the complexity of sustainable development. Proc ICE Eng Sustain 159:145-154

55. Jordan A, O'Riordan T (1997) Social institutions and climate change: applying cultural theory to practice. Norwich, Centre for Social and Economic Research on the Global Environment. p. 56

56. Bertelsmann S (2014) BTI 2014-Chile Country Report. Bertelsmann Stiftung, Gütersloh

57. Worldbank (NA). Development Research Group. Available at: http:// databank.worldbank.org. Accessed 13 Jan 2016.

58. Ministerio de Relaciones Exteriores (2015) Informe Anual Comercio Exterior de Chile 2014-2015. Departamento de Estudios Dirección General de Relaciones Económicas Internacionales. Available at: https://www.direcon. gob.cl/wp-content/uploads/2015/07/Informe-anual-de-Comercio-Exteriorde-Chile-2014-2015.pdf. Accessed 20 Oct 2015 (in Spanish)

59. Ministerio de Desarrollo Social (2014) CASEN. Situación de la pobreza en Chile Presentación de la nueva metodología de medición de la pobreza y síntesis de los principales resultados (in Spanish)., Available online at: http:// observatorio.ministeriodesarrollosocial.gob.cl/documentos/Casen2013 Situacion_Pobreza_Chile.pdf. Accessed 4 Oct 2015 (in Spanish)

60. Yitzhaki, S (1979) Relative deprivation and the Gini coefficient. Q J Econ. 93: $321-24$

61. OECD (2015) Todos Juntos.¿Por qué reducir la desigualdad nos beneficia?... en Chile. Available at: http://www.oecd.org/chile/OECD2015-In-It-TogetherHighlights-Chile.pdf Accessed on 23 Jan 2016. (in Spanish).

62. Ministerio de Desarrollo Social (2012) Encuestra Casen. Available at: http:// www.redatam.org/redchl/mds/casen/casen2011/Index.html Accessed 28 Jan 2016 (in Spanish)

63. Etcheverry CAL (2009). Descentralización: La experiencia chilena, un estudio sobre los gobiernos regionales. Tékhne-Revista de Estudos Politécnicos, (11)145-71

64. Ministero del Interior (2005) DFL 1-19175: Fija el texto refundido, coordinado, sistematizado y actualizado de la Ley № 19.175, orgánica constitucional sobre gobierno y administración regional, Biblioteca del Congreso Nacional de Chile. (in Spanish)

65. Subsecretaría de Desarrollo Regional y Administrativo (SUBDERE) (2011) Misión, visión y ejes estratégicos de la SUBDERE., Available at: http://www. subdere.gov.cl/documentacion/misión-visión-y-ejes-estratégicos-de-lasubdere-0. Accessed 21 Jan 2016 (in Spanish)

66. Pressacco CF, Rivera S (2015) Democracia, participación y espacio local en Chile. Papel Político 20(1):65-89 (in Spanish)

67. Monje-Reyes PA (2015) La Teoría Crítica como perspectiva de análisis de las relaciones de dominación y los procesos de descentralización en Chile. Cadernos EBAPE BR 13(2):402-409, in Spanish
68. Pollitt MG (2004) Electricity reform in Chile: lessons for developing countries. CMI Electricity Project Working Paper, No.51, Department of Applied Economics, University of Cambridge, United Kingdom

69. Jadresic A (2000) Promoting private investment in rural electrification: the case of Chile

70. Comision Nacional de Energia (CNE) (NA). Available at: http://www.cne.cl/ quienes-somos/. Accessed 22 Sept 2015. (in Spanish)

71. Central de Energia (NA). Autoridad - coordinación. Available at: http://www. centralenergia.cl/actores/autoridad-energia-chile/. Accessed 30 Apr 2016 (in Spanish)

72. Comision Nacional de Energia (CNE) (NAb). Balance nacional de energía. Available at: http://energiaabierta.cne.cl/visualizaciones/balance-de-energia/. Accessed 19 Sept 2015. (in Spanish)

73. Comision Nacional de Energia (CNE) (2009), Non-conventional renewable energy in the Chilean electricity market, Comision Nacional de Energia (CNE) and Deutsche Gesellschaft fur Technische Zusammenarbeit (GTZ) $\mathrm{GmbH}$, Santiago, 2009

74. Generadores de Chile AG (2015) Boletín del Mercado Eléctrico. Sector Generacion, (in Spanish)

75. Congreso Nacional de Chile (2013) Introduce Modificaciones A La Ley General De Servicios Eléctricos Respecto De La Generación De Energía Eléctrica Con Fuentes De Energías Renovables No Convencionales (in Spanish)

76. Senado de Chile 2012. Available at: http://www.senado.cl/appsenado/ templates/tramitacion/index.php?boletin_ini=6041-08. Accessed 14 June 2014 (in Spanish)

77. Ministerio de Desarrollo Social (2013) Proyectos de electrificacion rural sistemas de autogeneración (in Spanish)

78. Ministerio de Desarrollo Social (2015) Metodología De Formulación Y Evaluación De Proyectos de Electrificación Rural., Available online: http:// documentslide.com/documents/metodologia-de-formulacion-y-evaluacionde-proyectos-de-electrificacion-rural.html. Accessed 11 Nov 2015 (in Spanish)

79. Barnes D (2005) Meeting the challenge of rural electrification in developing nations: the experience of successful programs. Energy Sector Management Assistance Program (ESMAP) World Bank, Washington DC, Conference Version, March (pp. 1-16)

80. Ministero del Interior y Seguridad Publica (DIPRES) (2012) Informe De Cumplimientos De Compromisos al 30-06-2012. Programa Electrificación Rural (PER). Availabe at: http://www.dipres.gob.cl/595/articles-109309_doc_ pdf.pdf Accessed 25 Oct 2016 (in Spanish)

81. Estay C (2006) Remocion de Barreras para la electrificacion rural con energias renovables., Informe Catastro de Campo XI Region, (in Spanish)

82. Rodriguez H (2012) Programa Remoción de Barreras para la Electrificación Rural. UNDP-GEF Project (Project CHI/00/G32 (11799) (in Spanish)

83. Instituto Nacinoal de Normalizacion (INN) (2006) Listado de Normas Chilenas Por CIN. (in Spanish)

84. IEnergia (NA). Adquisición e Instalación de Sistemas de Bombeo Fotovoltaico Licitación Pública No 609-177-LP11. Available at: https://www. mercadopublico.cl/Home. Accessed 4 May 2016 (in Spanish)

85. Doberti G (2013) ERNC en la Agricultura familiar campesina y Programa Nacional de Bombeo Fotovoltaico INDAP. (in Spanish)

86. Flick U, von Kardoff E, \& Steinke, I. (Eds.). (2004). A companion to qualitative research. Sage, London

87. MAXQDA (2016). Software for qualitative data analysis, 1989-2016, VERBI Software - Consult - Sozialforschung GmbH, Berlin, Germany. Available at: http://www.maxqda.com/

88. Susskind L, Kausel T, Aylwin J, Fierman E (2014) The future of hydropower in Chile. J Energy Nat Resour Law. 32(4):425-481

89. Deuman (2012) Evaluación Ex-Post del Primer Proyecto de Electrificación Mediante Sistemas Fotovoltaicos en las Comunas de Tortel, Villa Ó Higgins y Cochrane de la Provincia de Capitán Prat, Región de Aysén del General Carlos Ibáñez del Campo. (in Spanish)

90. Covarrubias F, Irarrázaval I, Galáz R (2005) Programa de Asistencia a la Gestión del Sector de la Energía: Desafíos de la Electrificación Rural en Chile. Banco Internacional de Reconstrucción y Fomento, Washington, D.C

91. Nerini FF, Broad O, Mentis D, Welsch M, Bazilian M, Howells M (2016) A cost comparison of technology approaches for improving access to electricity services. Energy 95:255-265

92. Gobierno Regional de Aysén (NA). SISTEMAS DE GENERACION FOTOVOLTAICOS VARIOS SECTORES COMUNA DE AYSEN CODIGO BIP: 30125568 - 0. Available at: https://www.mercadopublico.cl/Procurement/ 
Modules/Attachment/NiewAttachment.aspx?enc=POxTpc8k5kEehmdX 82SavZIQCfSKkB5w\%2fMuND7DysolmQMtod18DSfVAjxSA77MO taEelk6qsw6Y804hSA6nr45\%2b8ndDK\%2b3WmB23KeufdQlbaBcUcpmlF 9E9Z5TiT00pEgAvs1lvZFCICIDRphX58IpxZyTMBIE5zvsj1 1il2HWizs4gLOxZyA frovwOwyuFqPN6TJw\%2bUKvPU0x0806ZStxBblsfOB9ibwT8rQoSADfPOj Wko4sZCKexwXnllpzGoaBPHPa3ci527OsAIP7qYdcSAcRApjPp3lhdwjfq QieKylQ\%2fSUyz6lEGSYceVDRfs. Accessed 22 Sept 2016.

93. Comision Nacional de Energia (CNE) (2002) Proyecto CHI/00/G32. Remocion de barreras para la electrificacion rural con Energias Renovables. Proyecto Fotovoltaico IVa Region de Coquimbo. Analisis y Evaluacion de posibles esquemas de gestion. (in Spanish)

94. Ministerio de Energia (2014) Agenda de Energía. Un Desafío País, Progreso Para Todos. Available at: http://www.cumplimiento.gob.cl/wp-content/ uploads/2014/03/AgendaEnergiaMAYO2014_FINAL.pdf. Accessed 1 June 2016. (in Spanish)

95. Navarro P, Titelman E, Twyman C (2005) Informe Final Programa De Electrificación Rural. Ministerio Del Interior Comisión Nacional De Energía Subsecretaria De Desarrollo Regional Y Administrativo. Available at: http://uww.dipres.gob.cl/595/ articles-141050 informe final.pdf. Accessed 18 Sept 2016. (in Spanish)

96. Jiménez-Estévez GA, Palma-Behnke R, Ortiz-Villalba D, Mata ON, Montes CS (2014) It takes a village: social SCADA and approaches to community engagement in isolated microgrids. IEEE Power and Energy Magazine 12(4):60-69

97. Ministero del Interior y Seguridad Publica DIPRES (2014b) Informe De Cumplimientos De Compromisos al 30-06-2014. Programa Electrificación Rural (PER). Available at: http://www.dipres.gob.cl/574/articles-94552_doc_ pdf.pdf. Accessed 5 Sept 2015 (in Spanish)

98. Climate Analytics, Ecofys and Potsdam Institute for Climate Impact Research (2016) Are countries on track for $2^{\circ} \mathrm{C}$ or $1.5^{\circ} \mathrm{C}$ goals?., Available at: http://climateactiontracker.org/countries/chile.html. Accessed 1 Mar 2016

99. Ministerio de Medio Ambiente (2014) Anteproyecto De Contribución Nacional Tentativa (Indc) En El Contexto Del Tratado Climático 2015 A Ser Finalizado En La Vigesimo Primera Conferencia De Las Partes (Cop21) De La Convencion Marco De Naciones Unidas Sobre Cambio Climático. Available at: http://portal.mma.gob.cl/consultacontribucion/. Accessed on: 21 January 2016 (in Spanish)

100. Ministero del Interior y Seguridad Publica (DIPRES) (2014b) Presupuesto por partida 2014. Proyecto de Ley de Presupuestos 2014 Available at http://www.dipres.gob.cl/594/articles-109104_Gasto_por_Partida_2014.pdf. Accessed 27 Mar 2015 (in Spanish)

101. Comision Nacional de Energia (CNE) (2015) Capacidad Instalada por Sistema Electrico Nacional., Available at: http://www.cne.cl/en/estadisticas/ electricidad/. Accessed 15 Feb 2016

102. Hernando A (2014) El sector energético en Chile y la Agenda de Energía 2014: Algunos elementos para la discusión. Centro de Estudios Publicos. (in Spanish)

103. Comisión Ciudadana-Técnico-Parlamentaria para la Política y la Matriz Eléctrica (CCTP) (2011) Chile Necesita una Gran Reforma Energética. Available at: http://www.patagoniasinrepresas.cl/final/dinamicos/chile_ necesita_una\%20gran_reforma_energetica.pdf Accessed on 17 June 2016. (in Spanish)

104. Barton JR (2013) Climate change adaptive capacity in Santiago de Chile: creating a governance regime for sustainability planning. Int J Urban Regional Res 37(6):1916-1933

105. Newbold J (2004) Balancing economic considerations and the rights of indigenous people. The Mapuche people of Chile. Sustain Dev 12(3):175-182

106. Almonacid Barría A (2014) Autoconsumo Fotovoltaico en Chile. Potencial y Barreras Energía Solar para la Generación de Electricidad y Calor. GIZ, Santiago de Chile (in Spanish)

107. Instituto Nacional de Estadistica (INE), (NA). VII encuesta de presupuestos familiares. (in Spanish). Available at: http://www.ine.cl/epf/base-de-datos. php. Accessed 14 Jan 2016

108. Ministerio de Energia (2016) Congreso Nacional aprueba proyecto de Equidad Tarifaria., Available at: http://www.energia.gob.cl/tema-de-interes/ congreso-nacional-aprueba-proyecto. Accessed 1 June 2016. (in Spanish)

109. Núñez O, Villalba DO, Palma-Behnke R (2013) Microrredes en la red eléctrica del futuro-caso Huatacondo. Ciencia y Tecnología: Revista de la Universidad de Costa Rica 29(2):1-16 (in Spanish)

110. HOMER (2011) Getting Started Guide for HOMER Legacy (Version 2.68). Available at: http://www.homerenergy.com/HOMER-getting-started-guide. html Accessed 8 July 2014
111. Ministerio de Desarrollo Social (NA). Banco Integrado de Proyectos (BIP). Available at: http://bip.ministeriodesarrollosocial.gob.cl/bip-consulta/. Accessed 14 Sept 2016 (in Spanish)

112. Comunidades Energéticas (NA). Luces y sombras para las comunidades energéticas aisladas en Patagonia. Documento de Trabajo. REDES- Conicyt. № 14001. Available at: http://www.comunidadesenergeticas.com/wpcontent/uploads/2016/04/Luces-y-sombras-para-las-comunidadesenergéticas-aisladas-en-Patagonia.23-marzo.pdf. Accessed 24 Apr 2016.

113. International Energy Agency (IEA) (2009) Chile: ENERGY POLICY REVIEW. ISBN 978-92-64-07314-2. Available at: https://www.iea.org/publications/ freepublications/publication/chile2009.pdf Accessed 14 May 2014.

114. Ministerio de Energía (NA). Proyectos DAEE. Available at: http:// proyectosdaee.minenergia.cl. Accessed 15 Sept 2016 (in Spanish)

115. GreenLab UC and Ingenergia DICTUC (2012) Estimación de Parámetros para Cuantificación de Beneficios Sociales y Externalidades en Proyectos de Energización., Santiago de Chile, (in Spanish)

116. Centro de Energía (NA). http://centroenergia.cl/?page_id=325. Accessed 15 Sept 2016 (in Spanish)

\section{Submit your manuscript to a SpringerOpen ${ }^{\circ}$ journal and benefit from:}

- Convenient online submission

- Rigorous peer review

- Immediate publication on acceptance

- Open access: articles freely available online

- High visibility within the field

- Retaining the copyright to your article

Submit your next manuscript at $\gg$ springeropen.com 